\title{
IPTEKS PERATURAN DAN KESADARAN WAJIB PAJAK TERHADAP KEPATUHAN WAJIB PAJAK KENDARAAN BERMOTOR PADA BADAN PENGELOLA PAJAK DAN RETRIBUSI DAERAH KOTA MANADO PROVINSI SULAWESI UTARA
}

\author{
Angraini P. Kalalo ${ }^{1}$, Grace B. Nangoi ${ }^{2}$ \\ ${ }^{1,2}$ Jurusan Akuntansi, Fakultas Ekonomi dan Bisnis, Universitas Sam Ratulangi, Jl. Kampus Bahu, Manado, \\ 95115, Indonesia \\ E-mail : anggikalalo15@gmail.com
}

\begin{abstract}
Tax is the responsibility of the people who are owed, either as individuals or business entities that aim to form laws, not directly and can be used for a large amount of people's prosperity. Payment of taxes is a manifestation of obligations and duties as well as tax obligations to participate and jointly. In accordance with the philosophy of the tax law, changing taxes is not only an obligation, but also for all countries for development.
\end{abstract}

Keywords : Tax, Tax Regulations, and Taxpayer Awareness

\section{PENDAHULUAN}

Pajak mempunyai pengaruh yang sangat penting bagi pendapatan negara, semakin wajib pajak lalai atau mengabaikan peraturan. Pendapatan negara akan semakin tinggi kalau masyarakat tidak membayar pajak. Pajak merupakan kewajiban masyarakat dalam membayarkan iuran pada negara. Bentuk pajak bersifat tidak bermoral (memaksa), ketika pajak tidak dibayarkan oleh masyarakat, maka wajib pajak akan dikenai hukuman yaitu denda dan tersitanya aset, dan melakukan penahanan kepada wajib pajak yang tidak mengikuti aturan dalam membayar pajak. Pajak mempunyai bebarapa ciri-ciri yaitu pajak secara langsung dan secara tidak langsung, pajak tidak juga harus dibayarkan dengan uang melainkan nilai kerja yang setara atau sama. Pajak adalah sesuatu yang harus dibayarkan untuk kas negara seperti bangunan, tanah, dan lain sebagainya. Selain itu pajak adalah investasi untuk masa yang akan datang agar terciptanya masyarakat untuk melakukan kewajiban membayar pajak.

Masyarakat atau wajib pajak harus mentaati, mengikuti, melaksanakan atau menjalankan peraturan pajak yang berlaku saat ini dan harus mempunyai kesadaran yang tinggi untuk bisa membayar pajak dengan itikad baik dan mempunayi rasa ikhlas dalam membayar pajak. Peraturan adalah aturan yang harus dijalankan oleh masyarakat dalam melakukan sesuatu agar terciptanya ketaatan agar tidak dikenai sanksi hukum yang berlaku. Kesadaran adalah tindakan atau perbuatan yang dilakukan secara sadar untuk melakukan dan menjalankan dan melaksanakan tanggung jawab diri sendiri agar tidak terjadi pelanggaran peraturan yang berlaku agar supaya tidak mempengaruhi hal posistif menjadi negatif. Dalam kesadaran wajib pajak, wajib pak harus mengetahui undang-undang tentang pajak, mengetahui fungsi pajak dengan benar.

\section{TINJAUAN PUSTAKA}

Pengertian Pajak. Pengertian Pajak menurut Adriani dalam Waluyo (2013:2) Pajak adalah pungutan masyarakat dan wajib dibayarkan karena itu merupakan pendapatan dari kita untuk negara yang harus dibayarkan secara langsung kepada pemerintah. Selain itu, pajak juga merupakan pungutan yang wajib dibayarkan rakyat kepada negara guna untuk kepentingan negara. 
Peraturan Pajak. Menurut Peraturan Pajak pada Undang-undang Ketentuan Umum dan Tata Cara Perpajakan Pasal 1(UU No.28 Tahun 2007) adalah aturan yang harus dilakukan oleh masyarakat dalam pendapatan negara, jika peraturan tersebut tidak ditetapkan maka wajib pajak tidak akan mempunyai kesadaran dalam membayar pajak dan akan dikenai sanksi hukum yang berlaku apabila tidak mengikuti peraturan yang telah ditetapkan.

Wajib Pajak. Kesadaran wajib pajak menurut Sapriadi (2013) dan Setiawan (2014) sangatlah berpangurh terhadap pemerintah, jika tidak terciptanya kesadaran wajib pajak akan melanggar peraturan yang ditetapkan dan akan dikenai sanksi hukum sesuai undang-undang yang berlaku. Kesadaran dalam membayar pajak harus dengan hati yang ikhlas dan tulus agar terciptanya komunaksi yang baik antara wajib pajak dan pemerintah.

\section{METODE DAN TEKNIK PENERAPAN IPTEKS}

\subsection{Metode Penerapan Ipteks}

Metode Ipteks, jika wajib pajak mengikuti peraturan dalam membayar pajak, dan mempunyai kesadaran dalam membayar pajak, maka pendapatan negara akan segera terpenuhi. Metode Ipteks yang diterapkan pada Kesadaran Wajib Pajak yaitu sangat mempunyai pengaruh yang baik atau pengaruh positif terhadap kepatuhan wajib pajak.

\subsection{Teknik Penerapan Ipteks}

Teknik penerapan Ipteks bahwa Wajib Pajak harus memahami kewajiban untuk negara dalam melaksanakan kewajiban membayar pajak dengan itikad yang baik.

\section{PEMBAHASAN}

\subsection{Gambaran Objek Penerapan Ipteks}

Pada tahun 1962 adalah tahun dimana Dinas Pendapatan Provinsi dibentuk. Dengan seiring perkembangan organisasi, Kantor Inspeksi Pajak mengalami perubahan nama instansi Dinas, menjadi Dinas Pajak dan Pendapatan pada tahun 1984 yang mengelolah pajak kendaraan bermotor (PKB). Dan setelah terjadi beberapakali perombakan nama instansi, sehingga menjadi Dispenda Provinsi Sulawesi Utara.

\subsection{Pembahasan}

Berdasarkan hasil penelitian pemerintah mempunyai peran yang sangat penting dalam meningkatkan peraturan serta kesadaran kendaraan bermotor. Tugas SAMSAT sebagai penyelengaraan pendaftaran dan identifikasi kendaraan bermotor, pembayaran pajak kendaraan bermotor dan pembayaran wajib dana kecelakaan yang terjadi dilalu lintas. Selain itu, tugas SAMSAT bagi masyarakat yaitu harus memberikan pelayanan, pemahaman serta informasi yang baik kepada masyarakat tentang bagaimana cara membayar pajak agar tidak terjadi kesalahan dalam pembayaran pajak untuk mengurangi tingkat pajak semua kendaraan bermotor. Tugas samsat harus juga memeberitahu dengan jelas apa saja sanksi yang akan dikenakan wajib pajak apabila wajib pajak tidak mentaati peraturan perpajakan dengan benar. Petugas juga harus sabar dan ramah terhadap masyarakat dalam membina, membimbing masyarakat agar terciptanya rasa nyaman antara petugas dan masyarakat dalam berkomunikasi juga menjadikan dorongan atau motivasi bagi masyarakat. Tugas serta wewenang Badan pengelola pajak dan retribusi daerah adalah merumuskan kebijakan teknis, pengembangan pendapatan, pembinaan, memotivasi, serta memberikan pelayanan umum pajak. Sedangkan tugas kewajiban dan tanggung jawab Badan pengelola pajak yatu melakasanakan tugas pemerintah daerah. Adapun struktur organisasi Badan pengelola Pajak dan Retribusi Daerah serta tugasnya:

1. Sekertaris, melaksanakan penyusunan tugas dibidangnya.

2. Bagian keuangan, mengatur keuangan dinas.

3. Bagian umum dan kepegawaian, menyelenggarakan urusan umum kepegawaian.

4. Bidang pendaftaran, melakukan koordinasi pendataan berkas. 
5. Seksi pendaftaran, melakukan registrasi subyek pajak daerah.

6. Seksi pendataan, mengambil data tentang pajak daerah.

7. Seksi pengelola data dan dokumentasi, menjalankan olah data dan dokumentasi.

8. Bidang penetapan penagihan, menghitung angsuran.

9. Bagian perhitungan, menghitung angsuran administrasi.

10. Bagian penerbitan, meneribitkan surat ketetapan pajak daerah.

11. Bagian penagihan, penagihan permohonan ketetapan pajak.

12. Bidang pelaporan, melakuakan evaluasi pendapatan.

13. Bagian pembukuan, melakukan pembukuan atas penerimaan pungutan benda berharga.

14. Bagian pelaporan, melaksanakan laporan penerimaan.

15. Bagian evaluasi, eveluasi pada pencapaian target.

16. Bagian pengendalian operasonal, melakukan koordinasi operasional.

17. Bagian penelitian, melakukan kegiatan penelitian penerimaan daerah.

18.Bagian pembinaan, pembinaan teknis pada pendapatan daerah.

Pada dasarnya setiap kendaraan bermotor, khususnya kendaraan roda dua, memiliki besaran pajak yang berbeda-beda. Nilai pajak tersebut bisa Anda lihat di Surat Tanda Nomor Kendaraan (STNK) motor. Berikut ini merupakan tabel Target Pendapatan Pajak Daerah Badan Pengelolah Pajak dan Retribusi Daerah Kota Manado Provinsi Sulawesi Utara :

Tabel 1. Target Pendapatan Pajak Daerah Badan Pengelolah Pajak dan Retribusi Daerah Kota Manado Provinsi Sulawesi Utara

\begin{tabular}{|c|c|c|}
\hline NO. & $\begin{array}{c}\text { UNIT KERJA / } \\
\text { JENIS PENERIMAAN }\end{array}$ & $\begin{array}{l}\text { TARGET TA. } 2018 \\
\text { (Rp.) }\end{array}$ \\
\hline \multirow{5}{*}{1} & PAJAK DAERAH & 1.000 .049 .416 .000 \\
\hline & Pajak Kendaraan Bermotor (PKB) & 318.136 .824 .684 \\
\hline & Nama Kendaraan Bermotor (BBN-KB) & 301.685 .786 .800 \\
\hline & Pajak Air Permukaan (PAP) & 1.625 .520 .800 \\
\hline & $\begin{array}{l}\text { Pajak Bahan Bakar Kendraan Bermotor } \\
\text { (PBB-KB) }\end{array}$ & 220.713.783.716 \\
\hline \multirow{8}{*}{2} & Pajak Rokok & 157.887 .500 .000 \\
\hline & LAIN-LAIN PAD YANG SAH & 6.050 .000 .000 \\
\hline & Denda Pajak Kendaraan Bermotor & 5.175 .000 .000 \\
\hline & Denda Bea Balik Nama Kendaraan & \\
\hline & Bermotor & \\
\hline & Pendapatn Kerja Sama Pemanfaatan & 875.000 .000 \\
\hline & Pendapata dari Pengembalian & - \\
\hline & Jumlah & 1.006.099.416.000 \\
\hline
\end{tabular}

Sumber : Dinas Pendapatan Daerah Provinsi Sulawesi Utara (2018)

Di dalam STNK juga tertera tanggal kapan harus membayarkan pajak. Jika terlambat membayarkan pajak dari tanggal yang tertera, maka akan dikenakan denda. Keterlambatan pembayaran pajak motor tampaknya masih sering terjadi keterlambatan bayar pajak bisa saja karena sang pemilik kendaraan lupa, tidak punya waktu karena sedang sibuk dengan pekerjaan, atau hal lain yang membuatnya tidak bisa bayar pajak tepat waktu. bagi wajib yang telat bayar pajak motor 1-2 hari hingga 1 bulan, maka akan dikenakan denda sebesar $25 \%$ dari pokok pajak yang wajib disetorkan. 


\section{KESIMPULAN DAN SARAN}

\subsection{Kesimpulan}

Ketika masyarakat atau wajib pajak tidak mengikuti aturan yang berlaku dan tidak mempunyai kesadaran dalam pembayaran pajak, maka pendapatan dinegara kita akan menjadi rendah.

\subsection{Saran}

Sebagai warga negara yang ingin negara kita maju dan berkembang, di dalam diri kita harus ada rasa tanggung jawab dalam menajalankan atau melaksanakan sesuatu, terlebih dalam membayar pajak. Karena kalau kita lalai dalam membayar pajak pendapatan untuk negara akan menjadi sempit. Karena pembayaran pajak tersebut digunakan untuk kepentingan umum.

\section{DAFTAR PUSTAKA}

Andi Donal Putra. 2017 Wahai Wajib Pajak di Http://ekonomi.kompas.com/read/2017/11/25/184103126/wahai-wajib-pajak-ketahuiaturan-terbaru-ini. (diaskes 25 November)

Badan Pengelola Pajak dan Retribusi Daerah Provinsi Sulawesi Utara. http://dispenda.sulutprov.go.id

Dharma, G. P. E, dan Suardana, K. A (2014). Pengaruh Kesadaran Wajib Pajak, Sosialisasi Perpajakan, Kualitas Pelayanan pada Kepatuhan Wajib Pajak, E-jurnal Akuntansi Universitas Udayana; 2014 Vol. 8, No.2

Mardiasmo, 2011. Perpajakan. Edisi Revisi. Yogyakarta: Andi

Rahayu, Siti Kurnia. 2010. Perpajakan Indonesia-Konsep dan Aspek Formal. Yogyakarta: Graha ilmu

Ritnawati, Juli, 2015. Dasar-dasar Perpajakan. Yogyakarta: CV Budi Utama

Undang-undang Republik Indonesia Nomor 6 Tahun 1983 tentang Ketentuan Umum Pajak dan Tata Cara Perpajakan

Undang-undang Nomor 28 Pasal 1 angka 1 tahun 207 tentang Ketentuan Umun dan Tata Cara Perpajakan

Undang-Undang Nomor 36 Tahun 2008 Perubahan Keempat Atas Undang-UndangNomor 7 Tahun 1983 tentang Pajak Penghasilan

Undang-undang Republik Indonesia Nomor 28 Tahun 2009 tentang Pajak Daerah dan Retribusi Daerah

Waluyo, (2012). Perpajakan Indonesia. (Buku 2 Edisi 10). Jakarta: Salemba Empat

Waluyo, 2011. Perpajakan Indonesia, Jakarta : Salemba Empat. Republik Indonesia, 